\title{
Women and Ecology: An Eco-Feminist Reading of Chinua Achebe's Things Fall Apart
}

\author{
Ifechelobi Jane Nkechi ${ }^{1}$, Asika Ikechukwu Emmanuel ${ }^{2}$ \\ ${ }^{1} \mathrm{PhD}$, Department of English, Nnamdi Azikiwe University, Awka \\ ${ }^{2} \mathrm{PhD}$, Department of English, Anambra State University, Igbariam
}

\begin{abstract}
Eco-feminism is based on the theory that the subjugation of women and the oppression of nature are linked together. Eco-feminism is linked to the study of the internal and intricate relationship between women and ecology. The theory projects that the subjugation of women and the oppression of nature are linked together. Discrimination and oppression due to power class, gender and race are directly related to the exploitation of the environment. In patriarchal societies, women and nature are ordinarily seen as fertile and capable of providing life, care and shelter. This paper highlights how Achebe uses the character of Ani, the earth goddess and Ezeani, the priest of the goddess, to showcase the similarities between women viz - a - viz their importance and nature in terms of fertility and production. It is equally an attempt to do a comparative analysis of the women in Things Fall Apart in line with nature. It $x$-rays the exploitation of women and environment in the novel. It will also explore the dominant male practices in Things Fall Apart relating to nature and women, how both are seen as innocent, female, productive and vulnerable to exploitation is the crux of the study.
\end{abstract}

Keywords- Nature, feminism, ecology, gender, society, patriarchal, culture, exploitation, oppression.

\section{INTRODUCTION}

Eco-feminism is a branch of criticism which seeks to analyze and interpret the relationship between women and nature. It describes movements and philosophies that link feminism with ecology. The term is believed to have been coined by the French writer Françoise d'Eaubonne in her book Le Féminisme ou la Mort in 1974. According to Mary Mellor:

Eco-feminism is a movement that sees a connection between the exploitation and degradation of the natural world and the subordination and oppression of women. It emerged in the mid-1970s alongside second-wave feminism and the green movement. Ecofeminism brings together elements of the feminist and green movements, while at the same time offering a challenge to both. It takes from the green movement a concern about the impact of human activities on the non-human world and from feminism the view of humanity as gendered in ways that subordinate, exploit and oppress women. (1)

Eco-feminism is interested in the particular and significant connections between women and nature; it seeks to interpret their repression and exploitation in terms of the repression and exploitation of the environment. Eco-feminists believe that these connections are illustrated through traditionally "female" values such as reciprocity, nurturing and cooperation, which are present both among women and in nature. Women and nature are also united through their shared history of oppression by a patriarchal Western society.

Women and nature are closely tied together and their role in society is predicated towards a common goal which is to nurture, reproduce and recreate. This is often ignored, neglected and exploited in a patriarchal world. Vandana Shiva in her opinion claims that women have a special connection to the environment through their daily interactions and this connection has been ignored. She says that women in subsistence economies who produce "wealth in partnership with nature, have been experts in their own right of holistic and ecological knowledge of nature's processes." However she makes the point that "these alternative modes of knowing, which are oriented to the social benefits and sustenance needs are not recognized by the capitalist reductionist paradigm, because it fails to perceive the interconnectedness of nature, or the connection of women's lives, work and knowledge with the creation of wealth. (3)

As Adrian Harris pointed out, Eco-feminists agree that the domination of women and the domination of nature are fundamentally connected and that environmental efforts are therefore integral with work to overcome the oppression of women. The primary aims of eco-feminism are not the same as those typically associated with liberal feminism. Ecofeminists do not seek equality with men as such, but aim for 
a liberation of women as women. Central to this liberation is a recognition of the value of the activities traditionally associated with women; childbirth, nurturing and the whole domestic arena. Some feminists have criticized ecofeminism for reinforcing oppressive stereotypes and for its tendency toward essentialism. According to him:

In Western society women are treated as inferior to men, 'nature' is treated as inferior to 'culture', and humans are understood as being separate from, and often superior to, the natural environment. Throughout our history nature is portrayed as feminine and women are often thought of as closer to nature than men. Women's physiological connection with birth and child care have partly led to this close association with nature. The menstrual cycle, which is linked to Lunar cycles, is also seen as evidence of women's closeness to the body and natural rhythms. Our cultural image of the 'premenstrual woman' as irrational and overemotional typifies this association between women, the body, nature and the irrational. Ecofeminists focus on these connections, and analyses how they devalue and oppress both 'women' and 'nature'. (10)

In all, Eco-feminism emphasizes the interdependence of all life, humanity's role as part of the earth's ecosystem, and the non-hierarchical nature of a system in which all parts affect each other are emphasized to counteract relationships dominated by values of control and oppression.

\section{CHINUA ACHEBE AND THINGS FALL APART: A REVIEW OF ALLIED LITERATURE}

Chinua Achebe's Things Fall Apart is reputed as one of the best books to have ever come from the African scene. It is one of the pioneering works that laid the foundation for Africa literature. Translated in over 58 languages in the world and recognized as one of the Africa's 100 Best Books of the $20^{\text {th }}$ century, Achebe's Things Fall Apart continues to blaze the trail and shed the light on the past, the present and the future of African literature. Sources have revealed that of all of Achebe's works, Things Fall Apart is the one read most often, and has generated the most critical response, examination, and literary criticism. It is studied widely in Europe, India and North America, where it has spawned numerous secondary and tertiary analytical works. Things Fall Apart is considered to be Achebe's magnum opus and Time Magazine included it in its TIME 100 Best Englishlanguage Novels from 1923 to 2005. According to Linda Strong Leek:
Things Fall Apart, first published in 1958, was initially written as a response to colonialist representations of Africa and Africans in literature, specifically Joyce Cary's Mister Johnson (1989). Cary's work positions Africans in the typical colonialist frame: as individuals without motives, forethought, or knowledge other than base responses to their environs. Asan Mohammed (1986) states, "colonial literature is an exploration of a world at the boundaries of civilization; a world that has not (yet) been domesticated by European signification." It is a world perceived as "uncontrollable, chaotic, unattainable, and ultimately evil."Against this context, Achebe's novel allowed European readers to perceive Africans through an alternate lens. The Igbo society described by Achebe has definitive and complex social systems, values and traditions. Achebe presents customs such as the abandonment of multiple birth babies, and the sacrifice of human beings as conventions and not barbaric, inhumane rituals. He brilliantly places his characters within an ancient civilization with a labyrinthine system of governance and laws... (29).

It is a fact well known that before the publication of Things Fall Apart, Europeans had written most novels about Africa, and they largely portrayed Africans as savages who needed to be enlightened by Europeans. Achebe broke apart this view by portraying Igbo society in a sympathetic light, which allows the reader to examine the effects of European colonialism from a different perspective. Achebe was able to prove the point that Africans did not hear of culture for the first time from the Europeans. According to him:

.... African people did not hear of culture for the first time from the Europeans; that their societies were not mindless but frequently had a philosophy of great depth and value and beauty. That they had poetry and above all, they had dignity. It is this dignity that many African people all but lost during the colonial period, and it is this that must now be regained. The worst thing that can happen to any people is the loss of their dignity and self-respect.... (8).

The language of the novel has not only intrigued critics but has also been a major factor in the emergence of the modern African novel. Because Achebe wrote in English, portrayed Igbo life from the point of view of an African man, and used the language of his people, he was able to greatly influence African novelists, who viewed him as a mentor. Achebe laid the foundation which many African writers continue to build on and expand the territories and frontiers 
of African literature. This is just as Linda Strong Leek

further maintained about the novel thus:

...though Achebe's text is written in English, the language of the colonizer, it remains authentically African: "Achebe is most successful in expressing his African experience in English and still preserving its African authenticity."The actions, ethos, and characterizations in the text depict a culture in transition, with indigenous practices which may be perceived as untenable to foreigners, but which are ordinary accepted within. Even when certain members of the community seek refuge in the Christian church, it is most often because they find themselves casualties of specific cultural norms: women who have multiple births, albinos, etc...rather than those who are secure in the traditional world...(30)

Things Fall Apart is a milestone in African literature. It has come to be seen as the archetypal modern African novel in English, and is read in Nigeria and throughout Africa. In the views of Moslem Zolfagharkhani and Reyhaneh Sadat Shadpour:

Things Fall Apart as Achebe's first novel is an influential story which helps the reader to develop a new understanding about the history, culture and place of Africa. Besides describing the life of African people before and during the colonization, this novel depicts the close relationship between the indigenous African life and nature. In this novel all of the stories which were narrated for the children were about nature and animals. Children had a close relationship with these concepts and could understand the meaning behind the story.(Nwoye) He remembered the story she often told of the quarrel between Earth and Sky long ago.... In fact, through these African narratives children learned about their original culture and the close relationship between nature and human beings. These stories taught humanity and morality with variant symbols in nature and proved that respecting nature is the corollary of these factors... (210)

According to Stella Okoye-Ugwu:

Part of the reason Achebe wrote Things Fall Apart was to portray the African ideal of a harmonious relationship between humans and the natural environment. He sets to capture a serene and tranquil traditional society full of love for one another and showcasing people living peacefully with natural elements. This is seen as what encapsulates the overall effect of Achebe's perspective on the African's link with land, so as to make the African readers realize what it was to dwell in a harmonious relationship with the physical environment... (156).

These are only but a selection of few critical commentaries available on Achebe and his Things Fall Apart. Over the years, Things Fall Apart has and will continue to generate critical commentaries from scholars in all generations as the novel will always be relevant not just to African readers, but foreigners in all cultures who would wish to be fully informed on the true nature of the African culture before the breakage brought about by colonialism, a breakaway that will remain indelible in the African consciousness. In all the ages, even the generations yet to come, Things Fall Apart will continue to remain relevant and of serious importance. One thing that will never be forgotten is that the achievement of Things Fall Apart set the foreground for numerous African novelists. It is quite true that because of Things Fall Apart, novelists after Achebe have been able to find an eloquent and effective mode for the expression of the particular social, historical, and cultural situation of modern Africa. Only the future will decide the fate of the book which has become an African classic.

\section{WOMEN AND ECOLOGY IN CHINUA ACHEBE THINGS FALL APART}

Like earlier emphasized, eco-feminism is tied to the study of the interval and intricate relationship between women and ecology. It seeks to account for the close connectivity and inseparable bond between women and nature in society. The theory projects that the subjugation of women and the oppression of nature are linked together. When women are oppressed and violated, nature is invariably threatened, and vis-à-vis when nature is at the receiving end of man's uncontrolled actions, women are also threatened. The exploitation of the women due to power class, gender and race are directly linked to the exploitation of our environment. All these are made manifest in Chinua Achebe's Thing Fall Apart. In the novel, Things Fall Apart, the writer, perhaps consciously or unconsciously revealed through his writing this interconnectedness between women and nature. Women in the novel were seen as the emblem of productivity, sustenance, fertility and continuity on whom the peace, prosperity and survival of the community heavily rest upon. Nature worked hand in hand to ensure the peace, stability and fertility of the whole community. In the novel, the writer presented to us the real values and role of the earth goddess, Ani. Ani was not just like any other goddess; she was the earth goddess, responsible for fertility and growth of crops on Umuofia. She oversees the harvest and blesses all hardworking farmers with bountiful harvest. This 
was why a week was devoted in her honour. It was the Week of Peace. The week is observed in between harvest season and the next planting season. Within this period of celebrating last years' harvest and getting ready to plant in the coming year, a week is devoted to honour the earth goddess without whose blessings the people's crops will not grow. Every man is at peace with his neighbour and no evil is committed or violence orchestrated during the period. It was even a taboo for someone to die during the Week of Peace. People only eat and exchange gifts freely with their neighbours. There was always enough to eat and drink in celebration of peace in other to appease the earth goddess for bountiful harvest. It was this Week of Peace that Okonkwo violated in his readiness to display his bravery and sheer heroism at all times. He had beaten his wife, Ojiugo during the week of peace for her inability to provide his meal at the appropriate time, a duty she abandoned to go and plait her hair. It was Ezeani, the priest on Ani that spelt out the implication of this abominable act to Okonkwo, thereby showing the role, value and importance of the earth goddess in the lives of the Umuofia people. He had reprimanded Okonkwo in these words:

'Listen to me,' he said when Okonkwo has spoken.

'You are not a stranger in Umuofia. You know as well as I do that our forefathers ordained that before we plant any crops in the earth we should observe a week in which a man does not say a harsh word to his neighbour. We live in peace with our fellows to honour our great goddess of the earth without whose blessing our crops will not grow. You have committed a great evil..... (24)

The priest went on to spell out the implications of his action alongside the level of which the Week of Peace must be respected. No offence should be reacted to during the week irrespective of the gravity of the offence. According to him:

Your wife was at fault, but even if you came into your obi and found her lover on top of her, you would still have committed a great evil to beat her... the evil you have done can ruin the whole clan. The earth goddess whom you have insulted may refuse to gave us her increase, and we shall all perish... (24).

Okonkwo was later to pay a fine of a she-goat, one hen, a length of cloth and hundred cowries which he added on his own a pot of palm-wine all meant for sacrifice to the goddess to show how repentant he was. This violation of the Week of Peace with the beating of Ojiugo has a lot of symbolic implication that an eco-feminist critic will find interesting and insightful. The incident is highly symbolic in the sense that it goes a long way to reveal the tie between women and nature. Nature is highly symbolic and powerful in the African context. In the opinions of Moslem Zolfagharkhani and Reyhaneh Sadat Shadpour:

The animate culture of Africa was based on the rules of nature; therefore it did not allow its people to treat each other with cruelty. When African people asked for the nature's blessing, they had to avoid injustice and immorality. Not only did nature have an impact on people's morality, but also it affected their decisions.... Every element of nature had an oracle on the earth and these Oracles had a leading rule in the life of African people. In fact, in the triangle of nature, religion and human being, these Oracles which were the most important components of religion made the communication between the other two parts possible. Before making decisions, Africans consulted with nature to get assured whether their mother earth would allow them. (212)

The moment Ojiugo was beaten, the earth goddess was offended and nature too, was violated. Ojiugo was beaten and made to cry, so was Ani goddess indirectly violated and desecrated. Coincidentally, it was during the Week of Peace and so Okonkwo must pay a price to placate the heart of the goddess which to a larger extent he placates the heart of Ojiugo.

Another festival that honours the goddess of Ani was the feast of the New Yam. It was an occasion for giving thanks to Ani, the earth goddess and the source of all fertility. Ani, was believed to play a greater part in the lives of the people more than any other deity. The writer described this thus:

The feast of the New Yam was held every year before the ancestral spirits of the clan. New yams could not be eaten until some had first been offered to these powers. Men and women, young and old, looked forward to the New Yam Festival because it began the season of plenty, the New Year. On that last night before the festival, Yams of the old year were all disposed of by those who still had them the new year must begin with tasty, fresh yam and nor the shriveled and fibrous crop of the precious year...(29).

The role and place of Ani, the earth goddess can never be over emphasized in Umuofia community. When Ani is pleased, the community enjoys fertility and great harvest. Little wonder why many women in Umuofia were productive inclusive the wives of Okonkwo. All Okonkwo's wives were gifted with the fruit of the womb except Ekwefi who continued to have Ogbanje children returned to her. She had buried almost nine children. But on a deeper thought, we could argue the cause of her problem with her 
somehow promiscuous life in the sense that unlike many other wives of Okonkwo, Ekwefi was the one who eloped with him. Ekwefi had fallen in love with Okonkwo's bravery after he defeated Amalinze, the Cat,but because his fortune was not much as of the time to pay her bride price she had taken another suitor. She had abandoned her husband two years later and came to live with Okonkwo. She was just on her way to the stream when she stopped over in Okokwo's house. Being a man of little words but actions, Okonkwo had taken her into his Obi and slept with her and that was how she became his wife. Such action may not have gone down well with the earth goddess and one might be compelled to believe that that was part of the reasons she was punished with Ogbanje children before Ezinma decided to stay to crown her joy of motherhood. But in all, women in the novel were productive and fertile and Ani, blesses them all,yet Okonkwo would always find a way to molest his wives and by so doing threaten the peace of the community. Apart from desecrating the Week of Peace, he beats his second wife, Ekwefi for merely plucking leaves from a banana tree. He had beaten her and while the woman was crying and muttering something about Okonkwo's gun that will never fire, Okonkwo almost killed her to prove to her that the gun has bullet and can kill. The writer captured this thus:

... and so when he called Ikemefuna to fetch his gun, the wife who had just been beaten murmured something about guns that never shot. Unfortunately for her, Okonkwo heard it and ran madly into his room for the loaded gun, ran out and aimed at her as she clambered over the dwarf wall of the barn. He pressed the trigger and there was a loud report accompanied by the wail of his wives and children. He threw down the gun and jumped into the barn, and there lay the woman, very much shaken and frightened but quite unhurt. He heaved a heavy sigh and went away with the gun (31).

Had Okonkwo succeed in his attempted murder, he would have destroyed the joy of the new yam festival and if that had been done, it would have spelt doom and despair from the wrath of Ani who must come for one of her own. The Ani goddess protects and watches over Umuofia people. He rewards labour. That was why Unoka was dismissed by the Agballa priestess when he came to complain on how has sacrificed to the deities but still reap a very small harvest. Unoka had complained thus:

'Every year, 'he said sadly, 'before I put any crop in the earth, I sacrifice a cock to Ani; the owner of all land. It is the law of our fathers. I also kill a cock at the shrine of Ifejioku, the god of Yams. I clear the bush and set fire to it when it is dry. I sow the yams when the first rain has fallen, and stake them when the young tendrils appear... (13).

The priestess hard criticized him thus:

'Hold your peace!" screamed the priestess, her voice terrible as it echoed through the dark void. 'You have offended neither the gods nor your fathers. And when a man is at peace with his gods and his ancestors, his harvest will be good or bad according to the strength of his arm. You, Unoka, are known in all the clan for the weakness of your machete and your hoe. When your neighbours go out with their axe to cut down virgin forest, you sow your yams on exhausted farms that take no labour to clear. They cross seven rivers to make their farms; you stay at home and offer sacrifices to a reluctant god. Go home and work like a man. (14)

Ani is also a protective goddess with equal justice. She stands as a balance between the living and the death. If a man commits any crime, Ani, the goddess will see to it. No member of the community will be killed without Ani marshaling out the right punishment to the culprit. That was why when Okonkwo accidentally killed the son of Ezeudu, Ani had to take her revenge to appease the soul of the deceased and the community at large. Okonkwo has to be punished thus; the only course open to Okonkwo was to flee from the clan. It was a crime against the earth goddess to kill a clansman. A man who committed it must flee from the land. The crime was of two kinds, male and female. Okonkwo had committed the female because it has been inadvertent. He could return to the clan after seven years (99). As Moslem Zolfagharkhani and Reyhaneh Sadat Shadpour project:

The culture of African people did not allow them to abuse nature. In fact, they asked their needs from the earth and sacrificed to appreciate its gifts and favors. The reason for which the colonizer tired to destroy this culture was because this culture did not allow the colonizer to exploit human beings and nature. Besides respecting nature, people had to respect themselves too, because they were considered as the children of the earth. "It is an abomination for a man to take his own life. It is an offense against the Earth, and a man who commits it will not be buried by his clansmen. His body is evil, and only strangers may touch it" (212).

Nature in the novel plays a protective role. It was an agent of comfort and succor which the women also provided for in the novel. Nature was always a source of hope, 
restoration and liberation to the people who await her gift at all time. The writer once described nature, her role and natural gift as well is what she represents in the lives of the people thus:

When the rain finally came, it was in large, solid drops of frozen water which the people called 'the nuts of the water of heaven! They were hard and painful on the body as they fell, yet young people ran about happily picking up the cold nuts and throwing them into their mouths to melt. The earth quickly came to life and the birds in the forests filtered around and chipped merrily. A vague scent of life and green vegetable was diffused into the air. As the rain began to fall move soberly and in small liquid drops, children south for shelter, and all were happily, refreshed and thankful... (104).

It was not just the children that find succor from this befitting role of the nature, adults do too. Their farms are dependent on the fairness of nature every planting season. Though nature could be a times destructive, nevertheless, the aggregate of her role to man is more humane, peaceful and source of comfort than her destructive poses. This is the same sought of serenity and comfort children find with their mothers. No wonder they grow more attached to them. Even Nwoye enjoys his mother's folktales than his father's tales of heroism. Whatever he did, he did it to please his father who would always want him to exhibit manly actions at all times but inwardly his heart is always with the mother in her hut and the stories she tells. Even men found this solace in nature. Okonkwo does too but he is always manly to admit or praise the preserving and soothing comfort which women bring. Some men connect with their women irrespective of their bravery, heroism and achievement. This is the case of Ogbuefi Ndulue. Ogbuefi Ndulue was the oldest man in Ire. Unlike Okonkwo, he had maintained a close tied relationship with his wives especially his first wife, Ozoemena. Both were said to have one mind and songs were fashioned with their names. They never did anything without telling the other. Little wonder that when Ogbuefi Ndulue died, Ozoemena came and called his name twice. She staggered back to her room and died in other to be united with her husband in the afterlife.

Women, like nature, provided the comfort the men always seek. Little wonder that when Okonkwo accidentally killed the son of Ezeudu during his burial, his mother's place was the only place he could find peace, shelter and comfort in the seven years of his exile from Umuofia. It was in Mbanta, his mother's place that Okonkwo came close to realizing the value and importance of women in life. They were not just for procreation and child bearing; they protect and give succor whenever it is needed. Just like the earth goddess, women give peace, shelter and harmony which men may never provide as they continue to sound the drum of violence and war. It was Uchendu, his Uncle that took him to explain the reality of this natural phenomenon, the interconnectivity between the earth and women to him in these words:

"It is true that a child belongs to its father. But when a father beat his child, it seeks sympathy in its mother's hut. A man belongs to his fatherland when things are good and life is sweet. But when there is sorrow and bitterness he finds refuge in his motherland. Your mother is there to protect you. She is buried there. And that is why we say that mother is supreme... (107).

It was at Mbanta that all these realization begin to dawn on Okonkwo. He was beginning to see women from different perspective. He later named his daughter, the one that was given birth to during his years of exile in Mbanta, Nnekawhich means 'mother is supreme' but that was perhaps only to appease his mother's people. Women are seen in the novel as agent of peace and they occupy various important roles in the community. They help in the farm, support a man and gave all the necessary involvement in training their children. Above all they are meant to be faithful to their husbands who go about the village bringing more girls home for marriage in tandem with the polygamous nature of man obtainable in a patriarchal society. Women, like nature are connected in one singular duty of peace and prosperity as well as fertility to the community, yet they are discriminated and limited in many ways as a result of the patriarchal cultures against them. Okonkwo was described as one man who does not take it easy with women. In some cases, the women appear as mere plaything to satisfy his sexual passions, give him children and it ends at that. None of them play any role in his decision and he always beat them at will, even to the point of almost shooting Ekwefi to death. The writer described him thus:

Okonkwo ruled his household with a heavy hand. his wives, especially the youngest, lived in perpetual fear of his fiery temper, and so did his little children perhaps down in his heart Okonkwo was not a cruel man. But his whole life was dominated by fear, the fear of failure and of weakness. It was deeper and more intimate than the fear of evil and capricious gods and of magic, the fear of the forest, and of the forces of nature, malevolent, red in tooth and claw. Okonkwo's fear was greater than these... (11) 
It was this fear that destroyed him in the end. Again is the case of Uzowulu who always beats and molests the wife until her people came and took her home. It took the egwugwu to convince Uzowulu to go with wine and bring his wife back.

Women are exploited and discriminated in many areas of life and this did not pass unnoticed by the writer. The writer captured some of these women under the bondage of tradition, culture, polygamy and the charades of a patriarchal society which invariably affect nature since women and nature share a common link from an ecofeminist perspective. Allie Fogle did well to capture some areas of subjugation and oppression of women in the novel, Things Fall Apart. From her study we can highlight some few areas she pointed out. The critic argues thus:

...times were strictly patriarchal; women were much suppressed, with a role that is limited. Women are seen but not heard. "The elders, or ndichie, met to hear a report of Okonkwo's mission. At the end they decided, as everybody knew they would, that the girl should go to Ogbuefi Udo to replace his murdered wife." Women are seen as replaceable, as they can be exchanged for one another. "As a matter of fact the tree was very much alive. Okonkwo's second wife had merely cut a few leaves off it to wrap some food, and she said so. Without further argument, Okonkwo gave her a sound beating and left her and her only daughter weeping." They are expected to be there for the men to beat if something goes wrong (even if it was not their fault). Women are seen as little better than slaves to men. Men take on more than one wife, many times within years; more wives mean more power to a man. The wives are expected to be there for the children but not to stand up for them. (1)

She went further to demonstrate with more examples thus:

[Odukwe]: "The law of Umuofia is that if a woman runs away from her husband her bride-price is returned." Women are treated like pieces of property, worth a set sum of money, which can be exchanged from man to man. However, women are allowed to run away from their husbands. There is no "punishable by death" law that keeps men and women together. They can separate, as long as the bride-price is returned. "With two beautiful grown-up daughters his return to Umuofia would attract considerable attention. His future sons-in-law would be men of authority in the clan. The poor and unknown would not dare come forth."
Okonkwo cares not for having daughters, just that they will help him to get back on top by giving them up to men of authority.... (1)

To this end, we believe that the writer obviously seeks for the liberation and fair treatment of these women which will go a long way to ensure peace, stability and harmony in our world. For when women are at peace and harmony, nature too, is at peace and will yield her dividends to full benefits the way a happy woman would yield all her sweet benefits to her man when her heart is happy and well pleased.

\section{CONCLUSION}

This paper attempts an eco-feminist enquiry into Achebe's Things Fall Apart with the singular aim of showcasing the role of women and their interconnection with nature. In all, we see that the ecology and women worked hand in hand to achieve an ideal, perfect and prosperous environment and the subjugation and ill-treatment against women is subjugation and maltreatment of nature. Women and nature are closely connected with each other, a connection which eco-feminism helps us to see. When women are exploited nature is exploited, and when nature is exploited, the society is threatened. The role of women and nature transcends beyond that of fertility and provision of care and shelter to other high purposes. Achebe in the novel, uses the character of Ani, the earth goddess and Ezeani, the priest of the goddess to showcase the other underlying intricacies and interplays as well as the similarities between women viz -aviz their importance and natural phenomenon in terms of fertility, productivity and stability that society is always in dire need of.

The women in Things Fall Apart are strong, submissive and duty conscious in the various positions they found themselves. Not many deviated or failed in her expected role of a mother and counselor. Too bad,Okonkwo found in his daughter, Ezinma the qualities and vigour he forever wished his sons especially Nwoye possessed. The women were role models and pillars of the society. Even Chielo, the priestess of Agballa still managed to combine effectively her duty as the priestess of Agballa and her motherly duty as a widow. No wonder Uchendu exposed the supremacy of women enshrined in these thoughtful words Nneka-mother is supreme. It may sound like a mere coincidence that the most potent medicine which carries and survives the whole Umuofia clan was made by an old woman with one leg. The medicine herself was called agadi-nwanyi, or old woman and the writer explained thus:

Umuofia was feared by all its neigbours. It was powerful in war and in magic, and it priests and 
medicine - men were feared in all the surrounding country. Its most potent war - medicine was as old as the clan itself. Nobody knew how old. But on one point there was general agreement the active principle in that medicine had been an old woman with one leg. In fact, the medicine itself was called agadi - nwanyi, or old woman. It had its shrine in the centre or Umuofia, in a cleared spot. And if anybody was so foolhardy as to pass by the shrine after dusk he will sure to see the old women hopping about (10).

It is interesting indeed that the greatest medicine that protects the whole of Umuofia clan and made them invincible in the eyes of other communities is traced to a woman. An old woman bears the burden and shoulders the gravity of the weight of the whole community, thus, emphasizing the essential role and place of women in the natural environment where they live. Yet, these women are constantly under exploitation by several cultural practices and traditional norms of our patriarchal societies. The male constantly in several ways oppress the women and unconsciously oppress nature which is tied to them. Women and nature in the novel are seen as innocent, female, productive but vulnerable to exploitation which men continue to exploit in many ways for their selfish desires. The liberation and emancipation of women would spell and connote the liberation and freedom of nature to certain extent and degree. In our societies today not only women are endangered but nature too in our continual struggle to make our world a global village. The message which must be left in our hearts is that women and nature ought to be free of many forms of exploitation and violation which is akin to violation against the only source of survival and existence. When we consider and implement this to the desired level, we may as well have carved out another niche for survival in our alien environment and may be on the move to safeguard our eco-system which is constantly becoming a threat to our survival and peace on earth.

\section{REFERENCES}

[1] Allie Fogle, "Feminist Analysis of Things Fall Apart by Chinua Achebe. December 12, 2012. Web.

[2] Achebe, Chinua. Things Fall Apart. Essex: Heinemann, 2008. Print.

[3] ---. "The Novelist as Teacher."African Writers on African Writing. Ed. G.D. Killiam. Evanston: NorthWestern University Press, 1973. Print.

[4] ---. "The Role of the Writer in a New Nation." African Writers on African Writing. Ed. G.D. Killiam.
Evanston: North-Western University Press, 1973. Print.

[5] ---. "The Portrait of a Writer as a Wordsmith: Discourse Techniques in Chinua Achebe's Things Fall Apart." Okike: An African Journal of New Writing. Number 50, October, 2013. Print.

[6] Baldwin, Gordon. Strange Peoples and Stranger Customs. New York: W. W. Norton and Company Inc, 1967. Print.

[7] Harris, Adrian. "The Green Fuse for Environmental Philosophy, Deep Ecology, Social Ecology, Ecofeminism, Earth-centered Spirituality". Last revised: November 2002. http://www.thegreenfuse.org/ (Accessed: 20/October/2015). Web.

[8] Linda Strong Leek. "Reading as a Woman: Chinua Achebe's Things Fall Apart and Feminist Criticism."African Studies Quarterly. Volume 5, issue 2, summer 2001. Web.

[9] Mary Mellor. Introduction to Feminism \& Ecology. New York: New York University Press, 1997. Web.

[10] Okoye-Ugwu, Stella." Going Green: Ecocritical Reading of Chinua Achebe's Things Fall Apart." Okike: An African Journal of New Writing. Number 50, October 2013. Print.

[11]Quinby, L. Ecofeminism and the Politics of Resistance. In I. Diamond \& G. F. Orenstein (Eds.), Reweaving the World: The Emergence of Ecofeminism (pp. 122-127). San Francisco: Sierra Club Books. 1990. Print.

[12] Reyhaneh Sadat Shadpour and Zolfagharkhani, Moslem. "An Eco-critical Study of Chinua Achebe's Things Fall Apart." Journal of Emerging Trends in Educational Research and Policy Studies (JETERAPS) 4(2):210-214. Print.

[13] Salleh, A. The Ecofeminism/Deep Ecology Debate: A Reply to Patriarchal Reason. Environmental Ethics, 14, 195-216. 1992. Web.

[14] Warren, K. J. The Power and Promise of Ecological Feminism. Environmental Ethics, 12, 125-146. 1990. Web. 